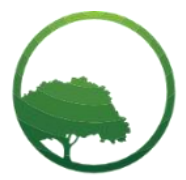

Business \& Social Science IJRBS

\section{Research in Business \& Social Science}

IJRBS VOL 10 NO 7 ISSN: 2147-4478

Available online at www.ssbfnet.com

Journal homepage: https://www.ssbfnet.com/ojs/index.php/ijrbs

\title{
The role of small town in household livelihood diversification in Ethiopia rural areas \\ Crossref
}

\author{
Kiros Nigus Tsegay ${ }^{(a) *(D)}$ Hongzhong Fan ${ }^{(b)}$ (D) Hailay Shifare ${ }^{(c)}$ (D) Priyangani Adikari ${ }^{(d)}$ \\ ${ }^{(a)}$ School of Economics, Huazhong University of Science and Technology, Wuhan 430074, China \\ ${ }^{(b)}$ Professor, School of Economics, Huazhong University of Science and Technology, Wuhan, 430074, China \\ ${ }^{\left({ }^{(c)} S c h o o l\right.}$ of Public Administration, Huazhong University of Science and Technology, Wuhan 430074, China \\ ${ }^{(d)}$ Department of Economics, Faculty of Social Sciences and Humanities, Rajarata University of Sri Lanka, Mihintale, 50300, Sri Lanka
}

\section{ARTICLE INFO}

\section{Article history:}

Received 29 September 2021

Received in rev. form 23 Oct. 2021

Accepted 29 October 2021

Keywords:

Small Town, Livelihood

diversification, Logistic Model

JEL Classification:

O15

\begin{abstract}
A B S T R A C T
There is a high expectation that urban-rural linkage in general and the function of small towns, in particular, has a great role in livelihood diversification and poverty reduction in rural areas than sectoral development. However, the previous empirical studies give little attention to the function of small towns and the livelihood diversification of rural communities. We analyze the function of a small town and participating in non-farm economic activities from a rural farm household survey of 371 farmer household heads in Ethiopia. The data was analyzed using a logistic regression model and statistical description. The study found that rural households who have road access have likely participated in none-farm activities and it has positive and significant effects. Education and FHH has also a significant relationship with the function of a small town. Distance from the small town has a significant and positive impact on the non-farm economic activities of rural communities. Overall, benefits from the function of small towns such as the provision of road access, agricultural extension, financial credit services, administrative services, educational and health services are some of the provisions of a small town. Therefore, a comprehensive integrated urban-rural linkage strategy could empower rural farm smallholders to diversify their livelihoods through strengthening small town functions is mandatory. The role of small towns needs to be integrated into rural communities. Participate in livelihood diversification strategies and achieve sustainable development goals by 2030 at large.
\end{abstract}

(C) 2021 by the authors. Licensee SSBFNET, Istanbul, Turkey. This article is an open access article distributed under the terms and conditions of the Creative Commons Attribution (CC BY) license (http://creativecommons.org/licenses/by/4.0/).

\section{Introduction}

Most of the developing countries especially the middle and low-income countries' economic activities are relying upon the agricultural sector to reduce poverty and bring about overall development. However, overall economic development and poverty reduction in such countries are improbable without rural development and extra livelihood diversification of smallholder farmers. This is because while a large proportion of the population depends on agriculture. With limited land, traditional farming, subsistence production, and poor utilization of agricultural technologies. In this case, non-farm economic activities account for a good part of rural household livelihood diversification ( Himanshu et al., 2017; Leng et al., 2020; Ma et al., 2018). Agriculture is a nucleus and engine of economic policies in Ethiopia (Baye 2017; Todaro 2012; Weldegebrial Gebru 2012). Nevertheless, rural development without corresponding and harmonious development of diverse economic activities in small towns may not be sustainable.

Livelihood diversification at the household level had a consequence in reducing rural poverty (Khatiwada et al. 2017). Because rural development should not depend only on-farm economic activities. Rural development activities must have integrated with regional, and urban non-farm activities (Himanshu et al. 2011, 2017; Jonasson and Helfand 2010). By implication, the linkage between the rural areas and the small town provides investment in transport infrastructure which is very pivotal to strengthen the linkages and

* Corresponding author. ORCID ID: 0000-0002-0163-1440

(C) 2021by the authors. Hosting by SSBFNET. Peer review under responsibility of Center for Strategic Studies in Business and Finance. https://doi.org/10.20525/ijrbs.v10i7.1407 
increase livelihood diversification of household farmers (Binswanger-Mkhize, McCalla, and Patel 2010). Infrastructural facilities are important to the interface among farm and non-farm activities across different sectors and geography, which is believed to be vital for rural growth (Montalvo and Ravallion 2010; Omotoso et al. 2020). The Economic, social, and administrative linkage in rural areas with the small town can lead to strong rural development and vice versa.

This rural-urban link reveals itself in many ways. For example; job creation, participating in non-farm economic activities, input, output, and information flows are among the main linkage elements (Andersson Djurfeldt 2012; Braun and Diaz-Bonilla 2008). The development of social and economic activities in the small town will benefit household head farmers of their hinterlands (Vandercasteelen et al. 2018), creating job opportunities to surrounding hinterlands (Shalina, Stepanova, and Drozdova 2021; Woods 2018). The small town provides the infrastructure to the hinterlands of the rural community such as all-weather roads, and improvement of transport of connection to their surrounding and smallholder farmers can diversify their livelihood from non-farm economic activities out of their farm (Albert and Benon 2016; Sadeghi and Branch 2021). However, the previous literature overlooking the function of a small town in participation of non-farm activities of the surrounding community could have a great role on farmers' livelihood diversification and reducing poverty via small town-rural linkage.

In addition, some of the prior findings conducted in Ethiopia have mainly focused on areas or people where there is a problem such as drought, pastoral societies, or semiarid environments. And rural household livelihood strategies in drought-prone areas (Eneyew and Bekele 2012; Gebrehiwot Weldegebrial Gebru 2012; Kahsay et al. 2019) did not relate the function of a small town in livelihood diversification of the surrounding rural communities in about infrastructure that could have a great role on farmer's livelihood diversification and reducing poverty via town-rural linkage.

As per our knowledge, almost no previous research has been conducted on the role of a small town on the livelihood diversification of smallholder farmers concerning infrastructure even though there are related topics with a different focus and research interest. For instance, research work by (Adem et al. 2018; Kassie, Kim, and Fellizar 2017a). In short, there is a need to investigate the role of small towns and infrastructure in diversifying the livelihood of farm household heads. Our objective in this paper was to investigate the role of a small town in diversifying the livelihood of the rural household heads in none/off-farm economic activities out of their farm using a logistic model.

This study was from the perspectives of central place theory versus growth pole theory supplementing the function of towns in livelihood diversification, which have mostly been ignored in the previous studies. In this study, the growth pole theory is linked with economic, social, and administrative issues. Assumed that such types of linkage help to rise involvement in non-farm economic activities for the rural household heads via strong linkage with the small-town dwellers. This study has a contribution to increasing the participation of non-farm economic activities in rural areas and sustainable economic development to reduce poverty. In Ethiopia, the bulk of the population lives in rural areas and is reliant on agriculture, and poverty is pervasive. Many factors might be blamed for the poor living conditions. Conflict, degrading environment, lack of infrastructure, or remoteness (Ahmed et al. 1970; Dercon and Gilligan 2008), endowments and shocks (Baulch and Hoddinott 2000; Dercon and Krishnan 1997), and poorly understood the rural non-farm sector and weak rural-urban linkage (Haggblade et al. 2002; Meikle 2014) are all factors. Given these obstacles, one way of reducing poverty is by bringing rural development. For the remainder, the next section has been organized as follows; part two, theoretical foundation and literature review, part three, materials and methods include a description of the study region. Section four analysis, discussion, and section five conclusions and areas for future research.

\section{Literature Review}

\section{Theoretical and Conceptual Background}

\section{The Central place theory}

Centrality explains every activity (function) of the city dispatched to the surrounding. However, the cities are distant from the rural communities. According to the central place theory, Concentration in urban caners was considered as spatial phenomenon-activities growing in or moving to one (or a few) urban places and forming bigger units (Steinführer, Vaishar, and Zapletalová 2016; Vaishar and Zapletalová 2009). Centralization is both a public and private sector phenomenon-the state is increasingly involved in the regulation of more and more economic activities while in the private sector larger and larger units control supply and stimulate demand for their products this results, the world's fastest-growing cities (Jedwab and Vollrath 2019). This theory encourages workers to do the job Mayer \& Knox (2010). As a result, these processes are accompanied by the movement of people from rural areas to cities by the movement of capital and entrepreneurs. Most countries result in high population growth rates in metropolitan areas.

Urbanization has become one of the main and more pressing challenges for developing countries (Castells-Quintana 2014). In this case, negative externalities become happened such as unmanageable population; unemployment, environmental impact, and increase energy and social cost. This will result if the megacities are located around the poor peripheral countries in this case both the rural communities and the urban dwellers can't benefit (Noronha and Vaz 2015).

Mayer \& Knox (2010) indicate that towns play an important function and act as a regional service center in rural hinterland expansion through direct production linkages, "spread "trickle-down" effects, barely and pieces of evidence has been found to suggest that small towns imitate rural neighborhoods development, and However small towns are not the wildest- growing places. Little can be expected 
in terms of trickle-down and spread effects this is also drawing dichotomy, and in keeping with new economic geography (NEG), it is recognized that urban and rural economies are progressively interdependent (Burton et al. 2013). By implication in this theory, smallholder farmers may have two options either looking at their agriculture as the only source of livelihood with subsistence farming or migrated to the cities for the search of jobs resulted from unemployment in rural areas.

\section{The Growth Pole Theory and the Role of Small Town to the Hinterland}

The growth pole theory was mostly used in the previous empirical study to test the theoretical background about urban-rural linkage and economic development to show the function of a town in the non-farm economic activities of smallholder farmers who are resident in the hinterland (Courtney et al. 2007; Mania and Rieber 2019). By implication, small towns play a great role to rural communities to involve in non-farm economic activities in addition to their agricultural activities and can reduce poverty. According to the growth pole theory, in the developing countries in areas where income was low and unemployment represented a problem. For these disadvantaged populations, growth center policies have functioned Fairley well (Bosworth 2017; Burton et al. 2013). Growth center policies (small towns) are the network of multi-purpose development centers (Kuhlmann and Wollmann 2011). The first establishment of small-town was in Britain in 1946. Nowadays, small towns have become commonplace globally to provide spillover populations from urban areas. This policy supports the principle of "jobs to the "workers" not for "workers to the job" (Mac Éinrí and White 2008; Scott 2006). Small towns are the network of multi-purpose development centers (Kuhlmann and Wollmann 2011). According to growth pole theory, the development of social and economic activities in the small town will benefit smallholder farmers off their hinterlands (Vandercasteelen et al. 2018). By creating job opportunities and none-farm activities in surrounding hinterlands (Shalina et al. 2021; Woods 2018). Infrastructure such as all-weather roads, and transportation of the border are more directly relevant when formulating de-concentration policies (Albert and Benon 2016; Sadeghi and Branch 2021). The first of these is employment generation Secondly, identifying the public facilities and economic infrastructure required for off-farm/non-farm employment expansion in rural areas remains relevant (Steinführer et al. 2016; Vaishar and Zapletalová 2009). Growth center policies remain of value for developing countries, especially if their economic base is related to agriculture and agro-processing. The reallocation of municipal infrastructure resources would be among the priority for a successful policy new business can diversify the economy and industry mix of a small town, making it resilient to economic change and entrepreneurship can be an important strategy for rural economic development (Constantine 2018).

According to Noronha and Vaz (2015), the sectoral development approach (urban versus rural areas) was decreasing its significance. Because such an approach does not give linkages between the rural areas and the small town. By advancing connectivity, small towns are useful for developing marketing outlets (demand) for rural homes. Backward connections, on the other hand, allow for the flow of inputs, managerial skills, technology, information, and loans into the agricultural and rural non-farm sectors (Teshome 2016). In this regard, rural areas' economy is often closely interwoven with economic activities in small towns. The linkages with (small) towns are so universal that the structure of the rural economy can vary in response to the economic and social functions in towns. Exhibited by the flow of farm and non-farm outputs for consumption and production purposes. The capacity of local regions to capture forward and backward linkages and their multiplier effects (Carriazo, Berdegue, and Soloaga 2015). The combined effect of strong forward and backward linkages can therefore be instrumental in increasing agricultural production and productivity, which eventually helps foster livelihood diversification of SHF. Moreover, it can help create a farm and non-farm employment opportunities and income, which contribute to poverty reduction and development in rural areas at large (Akkoyunlu 2015; Imai, Gaiha, and Garbero 2017). Missing functions in small towns can affect economic activities and rural development in many ways. However, small towns situated near rural areas can contribute to bridging part of that gap and play a significant role in facilitating rural development (Braun and Diaz-Bonilla 2008; Owen 2005).

\section{Infrastructure and Livelihood Diversification}

The presence of roads access in rural areas is vital for rural farm households to participate in non-farm economic activities. It implies that those household heads who have transportation access have more probability to involve in non-farm economic activities than those who do not have road access. (Benjamin 2013; Diao, Hazell, and Thurlow 2010; Sewell et al. 2019). Physical infrastructure such as transportation access has an impact on economic development. Due to connectivity between the rural areas and a town, increase the level of participation in non-farm economic activities. In addition, decreases both travel times and travel costs for goods and people this results in logistic benefits for the transportation of intermediate input and final output goods, and allows for faster and less costly commuting. Dorosh \& Thurlow (2013) investigated agriculture and small town in Africa they conclude the main role of the small town to the rural community is the linkage and connectivity among the small town and rural areas. Sewell et al (2019) research conducted by South Africa They apply cross-sectional data types from 200 respondents and employed A chi-square test method. They conclude that isolation is considering a major contributor to rural poverty. Suggesting the presence of road access in rural areas helps to reduce both the time and cost burden of the rural farmhouse heads. The study investigated In Poland Rokicki \&RStępniak (2018;., 2019) investigated about economic development they use data from 2004 to 2014 and employed the OLS method. Found that road accessibility and the employment regression are not statically significant. By implication, accessibility may not be positively correlated with regional economic growth in the end.

The study conducted by Colombian Barzin et al. ( 2018) investigated the dynamic effect of road and infrastructure panel data 20002009 to estimate the dynamic effect of road and they employ multiple estimation methods. Confirmed that transportation and 
infrastructure are comparatively more imperative in developing countries and it has a direct impact on livelihood diversification. Poor transportation infrastructure limits access to markets and public service for many residents of developing countries. In recent years, governments and multilateral organizations, have attempted to address this problem by making large investments towards the provision of roads. However, the positive impact of these investments is not well understood as infrastructure placement is usually driven (Aggarwal 2018; Maparu and Mazumder 2017). research conducted in rural Tanzania Aggarwal (2018) on the constraints of agricultural productivity and market concluded that the effect of rural road reducing travel costs by $50 \%$ and doubles adoption and reduce the adoption-remoteness by $18 \%$ this implies that by agriculture intensification and specialization rural household can diversify their livelihood sources. Most rural farm communities are live in remote and scattered areas and exist far from the center of the markets. Poor farmers are more likely to depend on subsistence farming to survive. This problem directly affects the livelihood diversification of smallholder farmers. research conducted in India on transport infrastructure and economic development according to Qin \& Zhang Qin and Zhang (2016) suggesting that developing rural areas may benefit from having access to connective infrastructure to urban nodes. If it facilitates commuting to metropolitan centers or the location of some business activity in rural areas, a network transportation facility has a favorable influence. The new facility, on the other hand, may solely benefit distant urban regions. It links, but at the cost of hastening the depopulation of rural areas in the interim. The spread and backwash effect by urban areas at the expense of the economic and demographic performance of rural areas is classic in that sense (Carriazo et al. 2015; Chen and Partridge 2013; Peón, Rodríguez-Álvarez, and López-Iglesias 2019).

Road access is the key interest for economic development and poverty reduction in rural areas by implication the road access improves the participation of rural farm households to involve in non-farm economic activities. Connectivity matters for the isolated and remote areas through the enormous road investment in sub-Saharan African does not seem to have produced the promised result. As the result in most African countries transport price remains the highest in the world and poverty has not declined in most rural areas (Dornan, 2016; Oliete Josa \& Magrinyà, 2018). In contradicts with the hypothesis of a positive sign and is also inconsistent with the above studies the households with access to the road are likely to reduce their probability of involvement in one-farm tasks by about 0.9 percentage as compared to those having no access to the road. This finding is also similar to the findings of (He, Town, and Samre 2013) rural households who have road access are less likely to diversify their none-farm activities. Small towns represent settlements where the necessary productive infrastructure and institutions are provided at a lower cost than normally would be required for scattered rural areas. And the development of towns can be a reason to provide feasible functions research conducted in Spain Agergaard et al. (Agergaard et al. 2019) on the effect of the new road suggesting the nearest municipality to the new road were beneficial in participating in non-farm economic activities than the remote areas. This finding is similar to the central place theory (spread) effect concluded that the spread effect did not disseminate to the neighboring municipalities. Small towns are important to the development of rural and urban areas through the functions they possess to promote employment and income opportunities by connecting and taking households closer to small towns where most of the non-farm employment opportunities and productive activities are concentrated.

Research conducted by Cameron Sen et al.,( 2021) suggesting that road access differs based on the initial degree of connectivity to the road network. Add the impact of road is either systematic or uniform. It is not one size fits all. While both rural and town households benefit from the functions, some major functions such as roads and transport services, fixed facilities, and markets can be instrumental in taking rural households closer to towns and urban areas where there are more non-farm employment, income and marketing opportunities. Research conducted in Latin America (Escobal et al. 2015; Sha and Azharianfar 2017). According to the authors, overall, the functions of the small town facilitate and strengthen the forward and backward linkages that are important to the development of a locally interwoven (rural-urban) economy and this linkage is vital for rural household heads to participate in nonfarm activities, in addition, their on-farm activities. Many rural households needed to travel to the nearby towns if they wanted to make use of the functions such as schools, major markets, and banks. Other vital infrastructure such as roads that cross rural areas can be partly considered as town functions as they connect rural households to towns thereby assisting them in various livelihood activities (Mahadevan and Suardi 2019) transport services. However, were limited to rural towns or towns, in which case they complement the functional services provided by roads that connect rural households to towns. Some other functions that were available in rural areas, such as primary schools, extension, and agricultural cooperative centers, also had higher and complex setups in rural towns and towns. Research conducted in Sub-Saharan Africa Dorosh et al. (2010) on crop production and road connectivity Currently, rural electrification, network, Water Provision in Ethiopia by the federal government is primarily meant to serve towns and rural towns. Roads may pass through several rural areas but many others are located far away from these road networks. This road network, however, continues to play a significant role in reducing transaction costs for input and output marketing, as well as non-farm job and income prospects in local and distant rural areas. However, if these road networks are not supplemented by transportation systems or if the roads are of poor quality, they may not contribute to more non-farm employment, income, or better connection.

Small towns, also provide important network functions to households in rural areas. In this regard, households can create and maintain network relations with households and productive activities in towns. Networks were recognized to contribute to households' choices of credit sources, market outlets, input sources, information sources (related to marketing and employment), and employment prospects. These networks and social capital are also vital as they act as 'rules of the game' in the production and consumption activities and enable positive rural-urban interactions (Adebisi et al. 2019). In this regard, functions that exist in different settlements (higher-order settlements like towns and cities) can be useful to financial activities and livelihood opportunities in rural areas. 


\section{Research and Methodology}

\section{Brief Background of the study area}

Data was gathered from Raya Azido district southern part of Tigray province. Tigray was found in Ethiopia's northern region. The region is bordered by Eritrea on the north, Sudan on the west, the south Amhara region, and the Afar region on the east. There are seven zones with 34 rural districts and 18 big cities. Generally, in a more dynamic agricultural region, the main livestock reared in this district are cattle, sheep, goats, and camels. Livestock is used as a source of draught food, and source of income in addition to crop production. In addition to Vegetables (Like; Onion, tomato, and hot pepper), Taaffe and sorghum are the dominant crops covering around $75 \%$ of the districts' cultivated land. However, the yield of these crops is very low (TEKA 2009)

\section{Location Map of the Study Area}

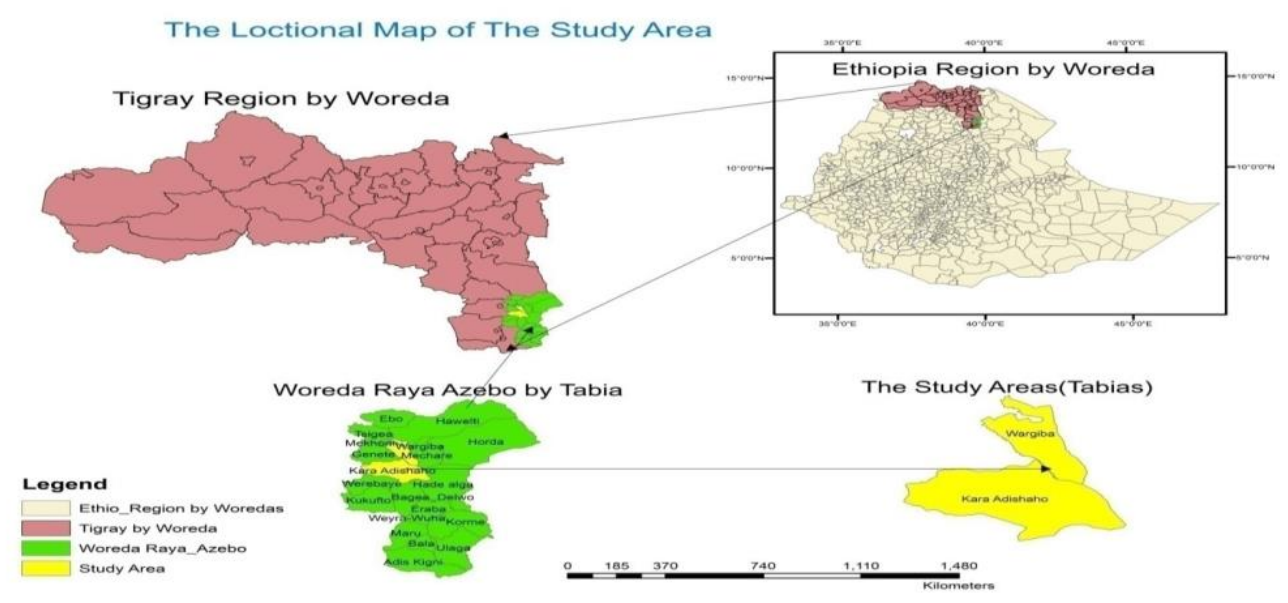

Figure 1: Map of the study area

\section{Quantitative survey data}

Quantitative survey data was our basis of data. Questionnaires were developed about the role of the small-town issue in analyzing and the aspects of livelihood sources; in diversified the livelihood of smallholder farmers; their source of livelihood from the sampled households; about the determinant factors for off/non-farm participating. The structured survey questionnaire was administrated with the help of data collectors and discussed the questions before the field survey. Rural household respondents were selected by following multiple sampling techniques. Systematic random sampling was used to select respondents from the list of farmers of each Tibia, which was found in the district. Probability sampling is an essential aspect of statistical methods to make some generalizations about the population (C.R. Kothari 2004; W.creswell 2013). Sample size was a determination by using the Slovenian formula (T.Isip 2010).

$\mathrm{n}=\mathrm{N} / 1+\mathrm{N}(\mathrm{e})^{2}$

$\mathrm{n}=$ required sample size

$\mathrm{N}=$ Total population size

$\mathrm{E}=$ the level of precision $(5 \%$ level of precision

Based on the above formula $\mathbf{3 7 1}$ rural households were selected from the $\mathbf{5 , 0 8 4}$ Target population of smallholder farmers. As we can see from the survey, the household heads can be characterized as the MHH and FHH.

\section{Qualitative data}

The mixing method was used. Nowadays, the majority of social scientists agreed that there are no core problem areas that should be studied completely with a single research technique. Besides, mixed methodologists explain the methodological effectiveness of the multiple methods. Therefore, using both methods helps to minimize the drawbacks of using qualitative or quantitative approaches. As philosophical support for mixed methods studies (W.creswell n.d.) in a quantitative study, the focus is on the representation of the subject and how variables interact, shape events, and arouse outcomes (Antwi and Kasim 2015), The qualitative study gives due attention to words rather than quantification (Antwi and Kasim 2015; Bryman, Becker, and Sempik 2008).

\section{Model Specification}

This article examined the effect of the determinant factors of livelihood diversification of smallholder farmers. To see the effect of the determinant factors consequently, we have constructed the conceptual model based on the logistic regression. This article has used important variables such as road access, distance from the small town, Educational, and Gender. The econometric models have used based variables (dependent and explanatory) rural houses hold heads can diversify their livelihood by participating in none/off- 
farm economic activities out of their farming. This may be affected by different factors. The dependent variable is smallholder farmers his/her sources using non-farm participation as": 1 if yes, 0 otherwise). The observation level here is the household head.

$Y i=\beta i \chi i+\varepsilon i$

$\mathrm{Y}$ is the latent variable observed by the following conditions;

$\mathrm{Yi}=1$ if $\mathrm{Yi}>0, \mathrm{Yi}=0$ otherwise

Where: $\mathrm{Y}$ is the dependent variable, This refers that smallholder farmers (Whether the household diversifies his/her livelihood strategy or not using non-farm participation as a proxy-based on the question that "is there any household member who participated in such activities during 2020 production year": 1 if yes, 0 otherwise (Alobo Loison 2019a; Kassie, Kim, and Fellizar 2017b).

\section{Results and Discussion}

\section{Non-farm Activities of Farm Households Heads}

Table 1: None-farm activities

\begin{tabular}{llllllllll}
\hline \multirow{2}{*}{ Tabia } & \multicolumn{3}{l}{ Petty trade } & \multicolumn{3}{l}{ Daily laborers } & \multicolumn{3}{c}{ Handcraft } \\
\cline { 2 - 11 } & No & Yes & Total & No & Yes & Total & No & Yes & Total \\
\hline Wargiba & 38 & 115 & 153 & 114 & 80 & 153 & 126 & 27 & 153 \\
\hline Kara Adishu & 71 & 147 & 218 & 138 & 39 & 218 & 203 & 15 & 218 \\
\hline Total & 109 & 262 & 371 & 252 & 119 & 371 & 329 & 42 & 371 \\
\hline
\end{tabular}

Source: Own computation from the survey Data (2020).

Table 1 showed that the respondents in the study area, involved in non-farm economic activities. The result indicated that the household heads participating in petty trade, daily labor, and handcrafting. However, petty trade and daily labor are frequently participated by the sampled farmers in both of the study areas than handcraft. The participation of households who are living in Kara is lower than the participation of Wargiba. The result may cause because of the location and distance from the small town to the household heads. However, the rural households who are living in Wargiba have an opportunity to partake in non-farm economic activities. Because Wargiba is found in an average distance of $12 \mathrm{~km}$ to the small town. Nevertheless, Kara found an average distance of $30 \mathrm{~km}$ from the small town. By implication, rural households who are living in Kara are wide-open lost their valuable time to pay another additional cost if we compare households who are living in Wargiba. For that reason, distance matters in the likelihood of the livelihood diversification of rural households. In the study area, the participation of the household in handcrafting is not significant this may be because of the existing social and cultural, and religious influence of the surrounding societies who are living in the study areas matter.

\section{Statistical Description About the Role of Small Town to Rural Household Heads.}

Table 2: The role of small-town

\begin{tabular}{|c|c|c|c|c|c|c|c|c|c|c|c|c|c|c|c|c|c|c|}
\hline & \multicolumn{3}{|c|}{$\begin{array}{l}\text { Agricultural } \\
\text { input }\end{array}$} & \multicolumn{3}{|c|}{$\begin{array}{l}\text { Administration } \\
\text { service }\end{array}$} & \multicolumn{3}{|c|}{ Credit access } & \multicolumn{3}{|c|}{ Market access } & \multicolumn{2}{|c|}{ Education } & \multicolumn{4}{|c|}{ Health } \\
\hline & 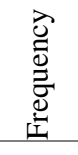 & $\begin{array}{l}\overrightarrow{0} \\
\stackrel{0}{0} \\
\text { 巳 }\end{array}$ & 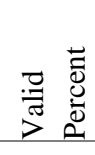 & 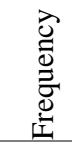 &  & 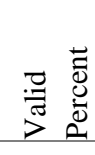 & 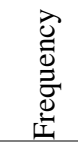 & 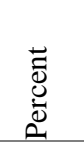 & ت류 & 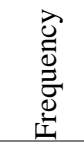 & 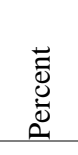 &  & 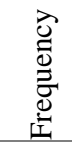 & $\begin{array}{l}\overrightarrow{0} \\
\text { U. } \\
\text { ص. }\end{array}$ &  & 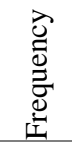 & 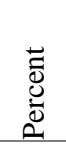 & 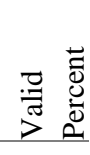 \\
\hline$\stackrel{0}{Z}$ & 92 & 24.7 & 24.8 & 120 & 32.3 & 32.3 & 77 & 20.7 & 20.8 & 98 & 26.3 & 26.4 & 87 & 23.4 & 23.5 & 56 & 15.1 & 15.1 \\
\hline$\stackrel{\theta}{\nu}$ & 279 & 75.0 & 75.2 & 251 & 67.5 & 67.7 & 294 & 79.0 & 79.2 & 273 & 73.4 & 73.6 & 284 & 76.3 & 76.5 & 315 & 84.7 & 84.9 \\
\hline हैं & 371 & 99.7 & 100.0 & 371 & 9.7 & 00.0 & 371 & 99.7 & 100.0 & 371 & 99.7 & 100.0 & 371 & 99.7 & 100.0 & 371 & 99.7 & 00.0 \\
\hline
\end{tabular}

Source: Survey data, 2020.

As indicated in table 2. From the total farmhouse holds, the small town is giving agricultural input access to $75 \%$ of the respondents. This indicated that the small town is vital for providing both agricultural input, output, social, instructional, and economic services. This result is consistent with the study of (Akkoyunlu 2015; Gebre and Gebremedhin 2019; He et al. 2013). As we see from the above table 2, from the total sample of household respondents 251 of them are getting a different kind of administrative services from the small town. The qualitative data indicates among the services provided by the small town to the hinterlands of the rural farm household are the extension service, social justice, social awareness, and extension service. The result is in harmony with the findings of (Kocho et al. 2011) from the total respondents about $79 \%$ are receiving access to financial credit and $74.4 \%$ received market access. In addition, the small town is providing public services. From the total sample of households of 371 respondents, 284 are receiving an educational opportunity from the small town. Moreover, from the total sample of rural farm household respondents 315 
of them are receiving health services from the data gained from the town health center. This is help full to the rural areas and the farm households to enhance their livelihood diversification. Overall, the above findings are similar to the study of (He et al. 2013) the function of a small town also has an important part in diversifying the rural livelihood, especially it is helpful for the farmers to contribute to non-farm economic activities. This is more significant for that are nearby the town and found around the small town. Because small towns are more probable to practice in non-farm economic activities than other people who are far away from the small town. For the nearby residents, the small town is providing and creating other new job employment to the nearby rural farm households. As indicated in the descriptive data of the sample 371-sample households 103 of them are engaged in the petty trade. Consequently, the small town adds to the livelihood diversification of its nearby rural household heads.

\section{Proximity and its opportunity}

Table 3: Tibia * Proximity advantage Cross tabulation

\begin{tabular}{llllll}
\hline Count & \multicolumn{3}{c}{} & \multirow{2}{*}{ Total } \\
\cline { 3 - 5 } & & \multicolumn{2}{l}{ Proximity advantage } & Low & \\
\cline { 2 - 5 } Tabia & High & 100 & 30 & Medium & 153 \\
& Wargiba & 85 & 98 & 35 & 218 \\
\hline \multirow{nyyyy}{*}{ Total } & Kara Adishu & 185 & 128 & 58 & 371
\end{tabular}

As indicated in table 3. From the total farmhouse holds, of 371 respondents 185 of them have high proximity advantage from the small town 128 have medium, and 58 of them receive proximity advantage from the small town. Both Kara and Wargiba's local administration of the study area found in the hinterlands of the small town. The small town is far about $85 \mathrm{~km}$ from the capital city of the Tigray region. The distance of the household from the nearby town has been found that it varies based on the resident place it is. Hence, in which Wargiba has found at an average of about $12 \mathrm{Km}$ and Kara has found at an average of about $30 \mathrm{Km}$ from the small town. As indicated in table 3. The proximity advantage is varies depending on the distance of the rural areas from the small town. For instance, Wargiba is the nearest to the small town relatively from Kara. The result shows that in Wargiba $65 \%$ of the respondents get a high proximity advantage from the small town and $19 \%$ medium $15 \%$ low proximity advantage from the small town. Whereas, in Kara $38 \%$ of the respondents have high proximity advantage 50\% medium, and $16 \%$ low. Research conducted in Spain by Agergaard et al. (2019) found that the effect of the new road suggesting the nearest municipality to the new road was beneficial in participating in non-farm economic activities than the remote areas. This finding is similar to the central place theory (spread) effect concluded that the spread effect did not disseminate to the neighboring municipalities. Small towns are vital to the growth of rural and urban areas through the functions they possess to promote employment and income opportunities by linking and taking households closer to small towns where most of the non-farm employment opportunities and productive activities are concentrated around the small town.

\section{Logistic Regression Model Result of off/none Farm Participation.}

The chi-square is $91.868 \%$, which is significant at 0.00 . According to the regression outcome the expected (B) result of the variable age, educational level presented positive signs at 3.406, 1.956, and 1.315 respectively, and at the same time statistically significant likelihood. Road access has a significant effect on livelihood diversification. In addition, education and being FHH have a positive and significant effect on the non-farm economic activities of rural households. In addition, distance from the small town has also a significant effect on livelihood diversification.

\section{Discussion}

Our study endeavored to investigate the function of a small town in non-farm participation from the perspective of infrastructure. We used the logistic regression model. Based on this our empirical evidence is indicated in the next finding. Variables like road access, education are statistically significant variables with positive expectations. Whereas, distance from the town has an insignificant effect on the livelihood diversification of the household heads. The overall result indicated that road access and education access, are the ways of increasing livelihood diversification of farm households out of their farm, this demonstrated household heads who have road access and education access are the key contributors of livelihood diversification.

\section{Road access}

It has statistically significant, has a positive impact with a coefficient of 1.315 and has a great role in the livelihood diversification of smallholder farmers in the rural areas. The result was our proposed hypothesis. Household heads who have road access have a greater probability of their livelihood diversification than the households who have not access roads in the rural areas. This finding corroborates with the work of (Benjamin 2013; Diao et al. 2010; Sewell et al. 2019). Connectivity reduces both travel times and travel costs these results in logistic benefits for the transportation of intermediate input and final output goods and allows for faster and less costly commuting. Dorosh \& Thurlow (2013) investigated agriculture and small town in Africa they conclude the main role of the small town to the rural community is the linkage and connectivity among the small town and rural areas. By implication, small towns had a great role in the livelihood diversification of smallholder farmers by providing road access to the rural areas. 


\section{Distance from the small town}

It has a positive and significant effect on none-farm activities. With a coefficient of 1.164. This indicating that household heads relatively near to the small town have increased their livelihood diversification. As the result indicated from the descriptive analysis, the participation of households who are living in Kara, which is far away from the small town, has lower than the participation of Wargiba near to the small town. The result may cause because of the location and distance from the small town to the household heads. However, the rural households who are living in Wargiba have an opportunity to partake in non-farm economic activities and as well to diversify their sources of livelihood. By implication distance matters in the likelihood of the livelihood diversification of the rural households. According to Sewell et al (2019) isolation is considering a major contributor to rural poverty. Suggesting the road infrastructure reduces the time burden of the rural communities, decreases transport costs, and most importantly fosters rural development. Households who are near to the small town were highly expected to diversify their livelihood diversification, but amazingly, it was not significant.

\section{Gender}

As reported in table 3, the result shows that female household heads have a positive and significant correlation with off/non-farm participation than male household heads implies that FHH is more active than MHH in participating in non-farm economic participation in the study area. This outcome is consistent with the findings of (Alobo Loison 2019b). However, it contradicts the findings of (Naybor, Poon, and Casas 2016) based on survey data from 153 respondents, who found MHH are more active in income sources generated from off-farm in Ethiopia. The qualitative data from the descriptive section showed that female households more participate in petty trade. Both rural and urban areas can benefit from the function of the small-town rural farm households who are closer to the town can benefit from road access, transport service, market access, employment opportunities, and income advantages. Research conducted in Latin America (Escobal et al. 2015; Sha and Azharianfar 2017). According to the authors, overall, the functions of the small town facilitate and strengthen the forward and backward linkages and this linkage is vital for rural household heads to participate in non-farm economic activities in addition to their on-farm activities. FHH who found around the small town is advantageous in participating in non-farm economic activities. Because the main challenge for FHH in participating in non-farm activities is the mobility problem resulted from farness (Asfaw et al. 2017; Kassie et al. 2017a).

\section{Education}

Educational has a significant correlation with livelihood diversification of farm households. The result was supported our proposed hypothesis. Household heads who performed formal education have a greater probability of their livelihood diversification than illiterate household heads. As indicated in table1, small-town provide educational and health services to rural farm households. From the total respondents of the total sample of 371 respondents, 284 are receiving an educational opportunity from the small town. In addition, from the total sample of rural farm household respondents 315 of them are receiving health services from the small town this could be help full in the rural areas and the farm households to enhance their livelihood diversification. This is corroborated by Getnet in Ethiopia (2021). However, contradicted the findings of Kassie et al (2017a) found educational level harms the diversification of livelihood. The data indicated that MHH is more participants in formal education than FHH.

Table 4: Model Summary

\begin{tabular}{llcc}
\hline Model Summary & & & \\
\hline Step & -2 Log likelihood & Cox \& Snell R Square & Nagelkerke R Square \\
\hline $\mathbf{1}$ & $287.290^{\mathrm{a}}$ & .354 & 504 \\
\hline
\end{tabular}

a. Estimation terminated at iteration number 6 because parameter estimates changed by less than .001 .

Table 5: Hosmer and Lemeshow Test

\begin{tabular}{|c|c|c|c|c|c|c|c|}
\hline Step & Chi-square & \multicolumn{3}{|c|}{ Df } & \multicolumn{2}{|c|}{ Sig. } & \\
\hline 1 & \multirow[t]{2}{*}{91.868} & & \multicolumn{2}{|l|}{8} & \multicolumn{2}{|c|}{.000} & \\
\hline \multicolumn{7}{|c|}{ Table 6: Variables in the Equation } & \\
\hline & & $\mathrm{B}$ & S.E. & Wald & df & Sig. & $\operatorname{Exp}(B)$ \\
\hline \multirow[t]{8}{*}{ Step $1^{\mathrm{a}}$} & Gender & -2.202 & .511 & 18.569 & 1 & .000 & 111 \\
\hline & Age & 3.406 & .520 & 42.861 & 1 & .000 & 30.145 \\
\hline & Education & 1.956 & .431 & 20.573 & 1 & .000 & 7.070 \\
\hline & Family size & 575 & .426 & 1.817 & 1 & .178 & 1.777 \\
\hline & credit access & -1.816 & .405 & 20.097 & 1 & .000 & .163 \\
\hline & road access & 1.315 & .508 & 6.698 & 1 & .010 & 3.726 \\
\hline & Distance from the town & 1.164 & .284 & 16.771 & 1 & 000 & 312 \\
\hline & Constant & -1.908 & .978 & 3.809 & 1 & .051 & .148 \\
\hline
\end{tabular}

Variable (s) entered on step 1: Gender, Age, Education, Family size, credit access, and road access, and distance from the town. 


\section{Conclusion}

The role of a small town such as road access was positively and significantly correlated with livelihood diversification that enables, the household heads who have road access can involve in non-farm activities than their counterparts. This result is consistent with the study of (Benjamin 2013; Diao et al. 2010; Sewell et al. 2019). The female-headed household has a positive effect on livelihood diversification. The small town is an advantage for the female-headed households to involve in non-farm activities. In addition, the small town provides educational and health services to rural households. Education has statistically significant coloration with nonfarm activities. In addition, distance from the small town has a positive and significant effect in increasing livelihood diversification. However, household heads who are relatively near to the small town were few participants in non-farm economic activities. Surprisingly, $15 \%$ of the respondents who are found near to the small town are not a participant in non-farm activities they may participant only on-farm activities.

Our result of the study has several implications for development policy both the Ethiopian government and developing countries at large. The governments must follow growth pole theory than sectoral development or agricultural fundamentalism approach. Urbanrural linkage in general and the role of a small town, in particular, can reduce poverty than sectoral development. Then the government should follow a small-town development policy rather than a dichotomous approach. The governments should follow a policy of combining the agricultural and the non-agricultural sector to increase livelihood diversification. In addition, targeting poverty reduction needs economic and social linkage not to interdependence each other. Because the singular focus on agricultural development cannot bring economic development.

Livelihood diversification for rural households needs all-rounded integration and cooperation between the rural areas and the small town. The strong relationship between rural areas and small towns strengthens the forward and backward linkage of both input and output relationships. Henceforth, the government policy and strategies must encourage the development of urban-rural linage and growth pole theory.

\section{References}

Adebisi, L. O., O. Jimoh, A. Jonathan, K. K. Osasona, and E. O. Ojediran (2019). Determinant of Farmers Participation and Repayment of Osun Rural Enterprise and Agricultural Program (OREAP) Micro-Credit Loan Scheme. Agro-Science 8(2):15. https://doi.org/10.4314/as.v18i2.3.

Adem, Mohammed, Esubalew Tadele, Habtamu Mossie, and Mezegebu Ayenalem (2018). Income Diversification and Food Security Situation in Ethiopia: A Review Study. Cogent Food \& Agriculture 4(1):1-17. https://doi.org/10.1080/23311932.2018.1513354.

Agergaard, Jytte, Cecilia Tacoli, Griet Steel, and Sinne Borby Ørtenblad (2019). Revisiting Rural-Urban Transformations and Small Town Development in Sub-Saharan Africa. European Journal of Development Research 31(1):2-11. https://doi.org/10.1057/s41287-018-0182-z.

Aggarwal, Shilpa (2018). Do Rural Roads Create Pathways out of Poverty? Evidence from India. Journal of Development Economics 133(January):375-95. https://doi.org/10.1016/j.jdeveco.2018.01.004.

Ahmed, Shaila, Sonia Shirin, Masuda Mohsena, Nargis Parvin, Niru Sultana, Samia Sayed, Rishad Mahzabeen, Masuma Akter, and Abu Sayeed. 1970. Geriatric Health Problems in a Rural Community of Bangladesh. Ibrahim Medical College Journal 1(2):17-20. https://doi.org/10.3329/imcj.v1i2.2900.

Akkoyunlu, Sule (2015). The Potential of Rural-Urban Linkages for Sustainable Development and Trade. International Journal of Sustainable Development \& World Policy 4(2):20-40. https://doi.org/10.18488/journal.26/2015). 4.2/26.2.20.40.

Albert, Byamugisha, and C. Basheka Benon (2016. Measuring the Performance of the Economic Infrastructure and Competitiveness Cluster in Uganda. Journal of Public Administration and Policy Research 8(1):1-11. https://doi.org/10.5897/jpapr2015). .0319 .

Alobo Loison, Sarah (2019a). Household Livelihood Diversification and Gender: Panel Evidence from Rural Kenya. Journal of Rural Studies 69(February 2017):156-72. https://doi.org/10.1016/j.jrurstud.2019.03.001.

Alobo Loison, Sarah (2019b). Household Livelihood Diversification and Gender: Panel Evidence from Rural Kenya. Journal of Rural Studies 69:156-72. https://doi.org/10.1016/j.jrurstud.2019.03.001.

Andersson Djurfeldt, Agnes (2012). Virtuous and Vicious Cycles in Rural-Urban Linkages: Cases from Zimbabwe. Africa Review 4(2):136-56. https://doi.org/10.1080/09744053.2012.782957.

Antwi, Stephen Kwadwo, and Hamza Kasim (2015). Qualitative and Quantitative Research Paradigms in Business Research: A Philosophical Reflection Performance Management Practices in the Ghanaian Local Government System View Project. European Journal of Business and Management 7(3):217-26.

Asfaw, Amogne, Belay Simane, Ali Hassen, and Amare Bantider (2017). Determinants of Non-Farm Livelihood Diversification: Evidence from Rainfed-Dependent Smallholder Farmers in Northcentral Ethiopia (Woleka Sub-Basin). Development Studies Research 4(1):22-36. https://doi.org/10.1080/21665095.2017). 1413411. 
Barzin, Samira, Sabine D’Costa, and Daniel J. Graham (2018). A Pseudo - Panel Approach to Estimating Dynamic Effects of Road Infrastructure on Firm Performance in a Developing Country Context. Regional Science and Urban Economics 70(December 2017):20-34. https://doi.org/10.1016/j.regsciurbeco.2018.02.002.

Baulch, B., and J. Hoddinott (2000). Economic Mobility and Poverty Dynamics in Developing Countries. Journal of Development Studies 36(6):1-24. https://doi.org/10.1080/00220380008422652.

Baye, Temesgen G. (2017). Poverty, Peasantry, and Agriculture in Ethiopia. Annals of Agrarian Science 15(3):420-30. https://doi.org/10.1016/j.aasci.2017). 04.002.

Benjamin, Emmanuel Olatunbosun (2013). Credit Risk Modelling and Sustainable Agriculture: Asset Evaluation and Rural Carbon Revenue. Journal of Sustainable Finance and Investment 3(1):57-69). https://doi.org/10.1080/20430795.2013.765382.

Beyene, Atakilte, David Gibbon, and Mitiku Haile (2006). Heterogeneity in Land Resources and Diversity in Farming Practices in Tigray, Ethiopia. Agricultural Systems 88(1):61-74. https://doi.org/10.1016/j.agsy.2005.06.004.

Binswanger-Mkhize, Hans P., Alex F. McCalla, and Praful Patel (2010). Structural Transformation and African Agriculture. Global Journal of Emerging Market Economies 2(2):113-52. https://doi.org/10.1177/097491011000200203.

Bosworth, Dr. Gary (2017). Economic Linkages between Urban and Rural Regions - What's In It for the Rural? Journal of Chemical Information and Modeling 53(9):21-25.

Braun, Joachim Von, and Eugenio Diaz-Bonilla (2008). Globalization of Food and Agriculture and the Poor. Food Policy 370.

Bryman, Alan, Saul Becker, and Joe Sepik (2008). Quality Criteria for Quantitative, Qualitative and Mixed Methods Research: A View from Social Policy. International Journal of Social Research Methodology 11(4):261-76. https://doi.org/10.1080/13645570701401644.

Burton, Linda M., Daniel T. Lichter, Regina S. Baker, and John M. Eason (2013). Inequality, Family Processes, and Health in the 'New' Rural America. American Behavioral Scientist 57(8):1128-51. https://doi.org/1177/0002764213487348.

C.R. Kothari (2004). Research Design.

Carriazo, Fernando, Julio A. Berdegue, and Isidro Soloaga (2015). Cities, Territories, and Inclusive Growth: Unraveling UrbanRural. 73:56-71. https://doi.org/10.1016/j.worlddev.2014.12.013.

Castaing Gachassin, Marie, Boris Najman, and Gaël Raballand (2015). Roads and Diversification of Activities in Rural Areas: A Cameroon Case Study. Development Policy Review 33(3):355-72. https://doi.org/10.1111/dpr.12111.

Castells-Quintana, David (2014). Malthus Living in a Slum: Urban Concentration, Infrastructures and Economic Growth.

Chen, Anping, and Mark D. Partridge (2013). Les Grandes Villes, à Quel Moment Sont-Elles Les Forces Motrices de La Croissance En Chine? Les Effets de Propagation et de Remous à Travers La Hiérarchie Urbaine. Regional Studies 47(8):1313-31. https://doi.org/10.1080/00343404.2011.589831.

Constantine, Lucia (2018). Understanding the Barriers and Opportunities to Latinx Entrepreneurship in Rural Communities. (April).

Courtney, P., Lucy M., Richard T., Philip J., and Andrew E.(2007). Small Towns as ' Sub-Poles ' in English Rural Development: Investigating Rural-Urban Linkages Using Sub-Regional Social Accounting Matrices. 38:1219-32. https://doi.org/10.1016/j.geoforum.2007.03.006.

Dercon, Stefan, and Daniel O. Gilligan (2008). The Impact of Agricultural Extension and Roads on Poverty and Consumption Growth in Fifteen Ethiopian Villages. (December).

Dercon, Stefan, and Pramila Krishnan (1997). In Sickness and in Health ... Risk-Sharing within Households in Rural Ethiopia Stefan Dercon and Pramila Krishnan.

Diao, Xinshen, Peter Hazell, and James Thurlow (2010). The Role of Agriculture in African Development. World Development. https://doi.org/10.1016/j.worlddev.2009.06.011.

Dornan, Matthew (2016. The Political Economy of Road Management Reform: Papua New Guinea's National Road Fund. Asia and the Pacific Policy Studies 3(3):443-57. https://doi.org/10.1002/app5.142.

Dorosh, Paul, and James Thurlow (2013). Agriculture and Small Towns in Africa. Agricultural Economics (United Kingdom) 44(45):449-59). https://doi.org/10.1111/agec.12027.

Dorosh, Paul, Hyoung-Gun Wang, Liang You, and Emily Schmidt (2010). Crop Production and Road Connectivity in Sub-Saharan Africa A Spatial Analysis. World Bank Policy Research Working Paper Series July 2010(5385).

Mac Éinrí, Piaras, and Allen White (2008). Immigration into the Republic of Ireland: A Bibliography of Recent Research. Irish Geography 41(2):151-79). https://doi.org/10.1080/00750770802076943.

Eneyew, Adugna, and Wagayehu Bekele (2012). Determinants of Livelihood Strategies in Wolaita, Southern Ethiopia. Agricultural Research and Reviews 1(5):153-1161.

Escobal, Javier, Arilson Favareto, Francisco Aguirre, and Carmen P. (2015). Linkage to Dynamic Markets and Rural Territorial Development in Latin America. World Development 73:44-55. https://doi.org/10.1016/j.worlddev.2014.09.017.

Gebre, Tewelde, and Berhanu Gebremedhin (2019). The Mutual Benefits of Promoting Rural-Urban Interdependence through Linked Ecosystem Services. Global Ecology and Conservation 20:e00707. https://doi.org/10.1016/j.gecco.2019.e00707.

Gebrehiwot Weldegebrial Gebru (2012). Rural Household Livelihood Strategies in Drought-Prone Areas: The Case of Gulomekeda District, Eastern Zone of Tigray National Regional State, Ethiopia. Journal of Stored Products and Postharvest Research 3(7):158-68). https://doi.org/10.5897/jsppr11.073. 
Getnet, Mersha Tewodros (2021). Rural Households Livelihood Portfolios and Determinates of Livelihood Diversi Cation in NorthWestern Ethiopia. 0-27.

Haggblade, Steven, Steven Haggblade, Peter Hazell, Peter Hazell, Thomas Reardon, and Thomas Reardon (2002). Strategies for Stimulating Poverty-Alleviating Growth in the Rural Nonfarm Economy in Developing Countries. EPTD Discussion Paper

He, Communities, Samre Town, and S Taharti Samre (2013). College Of Business And Economics Department Of Management The Thesis Entitled " The Role of Small Towns in Diversifying the Livelihood of Rural Communities.

Himanshu, Peter Lanjouw, Abhiroop Mukhopadhyay, and Rinku Murgai (2011). Non-Farm Diversification and Rural Poverty Decline: A Perspective from Indian Sample Survey and Village Study Data. 1-49.

Himanshu, Peter Lanjouw, Abhiroop Mukhopadhyay, and Rinku Murgai (2017). Agricultural Input Credit in Sub-Saharan Africa: Telling Myth from Facts. Food Policy 67:93-105. https://doi.org/10.1016/j.foodpol.2016.09.014.

Imai, Katsushi S., Raghav Gaiha, and Alessandra Garbero (2017). Poverty Reduction during the Rural-Urban Transformation: Rural Development Is Still More Important than Urbanisation §. Journal of Policy Modeling 39(6):963-82. https://doi.org/10.1016/j.jpolmod.2017). 10.002.

Jedwab, Remi, and Dietrich Vollrath (2019). The Urban Mortality Transition and Poor-Country Urbanization. American Economic Journal: Macroeconomics 11(1):223-75. https://doi.org/10.1257/mac.20170189.

Jonasson, Erik, and Steven M. Helfand (2010). How Important Are Locational Characteristics for Rural Non-Agricultural Employment? Lessons from Brazil. World Development 38(5):727-41. https://doi.org/10.1016/j.worlddev.2009.11.020.

Kahsay, Hailay Tsigab, Dawit Diriba Guta, Belay Simane Birhanu, Tagel Gebrehiwot Gidey, and Jayant K. R. (2019). Farmers' Perceptions of Climate Change Trends and Adaptation Strategies in Semiarid Highlands of Eastern Tigray, Northern Ethiopia. Advances in Meteorology . https://doi.org/10.1155/2019/3849210.

Kassie, Geremew Worku, Sangho Kim, and Francisco P. Fellizar (2017a). Determinant Factors of Livelihood Diversification: Evidence from Ethiopia. Cogent Social Sciences 3(1):1-16. https://doi.org/10.1080/23311886.2017). 1369490.

Kassie, Geremew Worku, Sangho Kim, and Francisco P. Fellizar (2017b). Determinant Factors of Livelihood Diversification: Evidence from Ethiopia. Cogent Social Sciences 3(1). https://doi.org/10.1080/23311886.2017). 1369490.

Khatiwada, Shanta Paudel, Wei Deng, Bikash Paudel, Janak Raj Khatiwada, Jifei Zhang, and Yi Su (2017). Household Livelihood Strategies and Implication for Poverty Reduction in Rural Areas of Central Nepal. Sustainability (Switzerland) 9(4):1-20. https://doi.org/10.3390/su9040612.

Kocho, Tsedeke, Girma Abebe, Azage Tegegne, and Berhanu Gebremedhin (2011) Marketing Value-Chain of Smallholder Sheep and Goats in Crop-Livestock Mixed Farming System of Alaba, Southern Ethiopia. Small Ruminant Research 96(2-3):1015. DOI: 10.1016/j.smallrumres.2011.01.008.

Kuhlmann, Sabine, and Hellmut Wollmann (2011). The Evaluation of Institutional Reforms at Sub-National Government Levels: A Still Neglected Research Agenda. Local Government Studies 37(5):479-94. https://doi.org/10.1080/03003930.2011.604542.

Leng, Chenxin, Wanglin Ma, Jianjun Tang, and Zhongkun Zhu (2020. ICT Adoption and Income Diversification among Rural Households in China. Applied Economics 52(33):3614-28). https://doi.org/10.1080/00036846.2020.1715338.

Ma, Wanglin, Alan Renwick, and Quentin Grafton (2018). Farm Machinery Use, off-Farm Employment and Farm Performance in China. Australian Journal of Agricultural and Resource Economics 62(2):279-98). https://doi.org/10.1111/1467-8489.12249.

Mahadevan, Renuka, and Sandy Suardi (2019). Panel Evidence on the Impact of Tourism Growth on Poverty, Poverty Gap and Income Inequality. Current Issues in Tourism 22(3):253-64. https://doi.org/10.1080/13683500.2017). 1375901.

Mania, Elodie, and Arsène Rieber (2019). Product Export Diversification and Sustainable Economic Growth in Developing Countries. Structural Change and Economic Dynamics 51:138-51. https://doi.org/10.1016/j.strueco.2019.08.006.

Maparu, Tuhin Subhra, and Tarak Nath Mazumder (2017). Transport Infrastructure, Economic Development and Urbanization in India (1990-2011): Is There Any Causal Relationship? Transportation Research Part A: Policy and Practice 100:319-36. https://doi.org/10.1016/j.tra.2017). 04.033.

Mayer, Heike, and Paul Knox (2010). Small-Town Sustainability: Prospects in the Second Modernity. European Planning Studies 18(10):1545-65. https://doi.org/10.1080/09654313.2010.504336.

Meikle, Sheilah (2014). The Urban Context and Poor People.

Montalvo, Jose G., and Martin Ravallion (2010. The Pattern of Growth and Poverty Reduction in China. Journal of Comparative Economics 38(1):2-16. https://doi.org/10.1016/j.jce.2009.10.005.

Naybor, Deborah, Jessie P. H. Poon, and Irene Casas (2016). Mobility Disadvantage and Livelihood Opportunities of Marginalized Widowed Women in Rural Uganda. Annals of the American Association of Geographers 106(2):404-12. DOI: 10.1080/00045608.2015). .1113110.

Noronha, Teresa De, and Eric Vaz (2015). Framing Urban Habitats: The Small and Medium Towns in the Peripheries. Habitat International 45:147-55. https://doi.org/10.1016/j.habitatint.2014.06.025.

Oliete Josa, Sergio, and Francesc Magrinyà (2018). Patchwork in an Interconnected World: The Challenges of Transport Networks in Sub-Saharan Africa*. Transport Reviews 38(6):710-36. https://doi.org/10.1080/01441647.2017). 1414899.

Omotoso, Abeeb Babatunde, Saidat Adebola Daud, Luke Okojie, and Abiodun Olusola Omotayo (2020). Rural Infrastructure and Production Efficiency of Food Crop Farmers: Implication for Rural Development in Nigeria. African Journal of Science, Technology, Innovation, and Development (October). https://doi.org/10.1080/20421338.2020.1821441. 
Owen, S. (2005). An Assessment of the Contribution of Small and Medium Scale Enterprises (SMEs) to the Manufacturing Sector in Small Urban Centres of Zimbabwe: A Case Study of SMEs in Bindura Town (Doctoral dissertation, University of Zimbabwe).

Peón, David, Jorge Rodríguez-Álvarez, and Edelmiro López-Iglesias (2019). Spread or Backwash: The Impact on Population Dynamics and Business Performance of a New Road in a Rural County of Galicia (Spain). Papers in Regional Science 98(6):2479-2502. https://doi.org/10.1111/pirs.12463.

Pretty, G. H., H. M. Chipuer, and P. Bramston (2003). Sense of Place amongst Adolescents and Adults in Two Rural Australian Towns: The Discriminating .... Journal of Environmental Psychology 23:273-87.

Qin, Yu, and Xiaobo Zhang (2016). The Road to Specialization in Agricultural Production: Evidence from Rural China. World Development 77:1-16. https://doi.org/10.1016/j.worlddev.2015). .08.007.

Rokicki, Bartlomiej, and Marcin Stępniak (2018). Major Transport Infrastructure Investment and Regional Economic Development - An Accessibility-Based Approach. Journal of Transport Geography 72(August):36-49). https://doi.org/10.1016/j.jtrangeo.2018.08.010.

Scott, M. (2006). Strategic Spatial Planning and Contested Ruralities: Insights from the Republic of Ireland. European Planning Studies 14(6):811-29). https://doi.org/10.1080/09654310500496149.

Sen, Binayak, Paul Dorosh, and Mansur Ahmed (2021). Moving out of Agriculture in Bangladesh: The Role of Farm, Non-Farm and Mixed Households. World Development 144:105479). https://doi.org/10.1016/j.worlddev.2021.105479.

Sewell, S. J., S. A. Desai, E. Mutsaa, and R. T. Lottering (2019). A Comparative Study of Community Perceptions Regarding the Role of Roads as a Poverty Alleviation Strategy in Rural Areas. Journal of Rural Studies 71(July):73-84. https://doi.org/10.1016/j.jrurstud.2019.09.001.

Sha, Naser, and Shahryar Azharianfar (2017). Urban-Rural Reciprocal Interaction Potential to Develop Weekly Markets and Regional Development in Iran. 61. https://doi.org/10.1016/j.habitatint.2017). 01.003.

Shalina, D. S., N. R. Stepanova, and A. V Drozdova (2021). Integrated Sustainable Development of Small Towns and Settlements. IOP Conference Series: Materials Science and Engineering 1079(5):052084. https://doi.org/10.1088/1757899x/1079/5/052084.

Smith, Harriet Elizabeth, Daniel Jones, Frank Vollmer, Sophia Baumert, Casey M. Ryan, Emily Woollen, Sá N. Lisboa, Mariana Carvalho, Janet A. Fisher, Ana C. Luz, Isla M. Grundy, and Genevieve Patenaude (2019). Urban Energy Transitions and Rural Income Generation: Sustainable Opportunities for Rural Development through Charcoal Production. World Development 113:237-45. https://doi.org/10.1016/j.worlddev.2018.08.024.

Steinführer, Annett, Antonín Vaishar, and Jana Zapletalová (2016). The Small Town In Rural Areas As An Underresearched Type Of Settlement. Editors ' Introduction To The Special Issue. 322-32. https://doi.org/10.1515/euro-2016-0023.

T.Isip, Frankling Bel (2010). Encouraging The Use Of Slovin's Formula In Computing Sizes in DMS Survei Related Projects. 1-5.

Gessesse, A. (2009). Analysis of fruit and vegetable market chains in Alamata, Southern Zone of Tigray: The case of onion, tomato and papaya (Doctoral dissertation, International Livestock Research Institute).

Teshome, Chala (2016). Analysis of Politics in the Land Tenure Systems: Experience of Successive Ethiopian Regimes since 1930. African Journal of Political Science and International Relations 10(6):111-18). https://doi.org/10.5897/AJPSIR2016.0919.

Todaro, Michael P (2012). The Developed and Developing World Income.

Toerien, Danie Francois (2018). The ' Small Town Paradox' and Towns of the Eastern Cape Karoo, South Africa. Journal of Arid Environments 154(April):89-98). https://doi.org/10.1016/j.jaridenv.2018.04.001.

Vaishar, Antonín, and Jana Zapletalová (2009). Small Towns As Centers Of Rural Micro-Regions. 70-81. https://doi.org/10.2478/v10091/009-0006-4.

Vandercasteelen, Joachim (2018). Big Cities, Small Towns, and Poor Farmers: Evidence from Ethiopia. World Development 106:393-406. https://doi.org/10.1016/j.worlddev.2018.03.006.

Vandercasteelen, Joachim, Seneshaw Tambru Beyene, Bart Minten, and Johan Swinnen (2018). Big Cities, Small Towns, and Poor Farmers: Evidence from Ethiopia. World Development 106:393-406. https://doi.org/10.1016/j.worlddev.2018.03.006.

Weldegebrial Gebru, Gebrehiwot (2012). Rural Household Livelihood Strategies in Drought-Prone Areas: A Case of Gulomekeda District, Eastern Zone of Tigray National Regional State, Ethiopia. Journal of Development and Agricultural Economics 4(6) https://doi.org/10.1016/10.5897/jdae12.126.

Woods, Michael (2018). Precarious Rural Cosmopolitanism: Negotiating Globalization, Migration, and Diversity in Irish Small Towns. Journal of Rural Studies 64(March):164-76. https://doi.org/10.1016/10.1016/j.jrurstud.2018.03.014.

Publisher's Note: SSBFNET stays neutral with regard to jurisdictional claims in published maps and institutional affiliations.

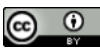

(C) 2021 by the authors. Licensee SSBFNET, Istanbul, Turkey. This article is an open access article distributed under the terms and conditions of the Creative Commons Attribution (CC BY) license (http://creativecommons.org/licenses/by/4.0/).

International Journal of Research in Business and Social Science (2147-4478) by SSBFNET is licensed under a Creative Commons Attribution 4.0 International License. 